\title{
Rastin Crowdfunding (RCF): A Financial Subsystem of Rastin Banking
}

\author{
Bijan Bidabad \\ B.A., M.Sc., Ph.D., Post-Doc. \\ Professor \\ Economics and Chief Islamic Banking Advisor \\ Bank Melli, Iran \\ E-mail:bijan@bidabad.com
}

\begin{abstract}
Expansion and development of social networks have provided new backgrounds for financial activities. Based on Rastin Banking Regulations, crowdfunding can be installed to apply social networks in the direction of Islamic finance. Two methods of crowdfunding are introduced in Rastin Crowd Funding. Sponsor Crowd Funding (SCF) is for the absorption of peoples' funds for special protective goals in the form of non-profit and free payments to an entrepreneur through banks. Peer to Peer Loan (PPL) is defined for absorption and collection of peoples' funds for extending interest-free loans to a specific project of an entrepreneur.Regarding the characteristics of crowdfunding and application of social networks, the Crowd Funding System (CFS) is used as a web-based portal for absorption and collection of money resources for crowdfunding project through social networks in Rastin Banking.
\end{abstract}

Keywords: Social networks, Crowdfunding, Rastin Banking, Sponsor Crowd Funding, Peer-to-Peer Loan, Rastin Crowd Funding System, Islamic Banking

\section{Introduction}

Crowdfunding/sourcing is a kind of financing based on collecting and participating people in profit and non-profit activities in various fields. ${ }^{1}$ In a general classification, Crowdfunding can be considered as the participation of all people, whether acquaintances or not, in relation to implementing a task/project. An idea or a topic is shared in crowdfunding to collect and accumulate resources to implement the idea or the introduced project. The proposed project can be a charity and non-profit or a profitable activity.

In Rastin Banking ${ }^{2}$, crowdfunding practically invites people to finance partially or totally a defined project ${ }^{3}$ of an entrepreneur ${ }^{4}$ through a financial grant, or loan. Regarding the mentioned characteristics, the method of work is

${ }^{1}$ See:

- Brabham, Daren C. (2008), Crowdsourcing as a Model for Problem Solving: An Introduction and Cases. Convergence: The International Journal of Research into New Media Technologies 14:1, 75-90.

- Brabham, D. C. (2009). Crowdsourcing the public participation process for planning projects. Planning Theory, 8(3), 242262.

- Zhao.Y, Zhu. Q. (2012). Evaluation on crowdsourcing research: current status and future direction. Springer science business media.

${ }^{2}$ In Rastin PLS banking, bank is a unit, which allocates resources from depositors to those who look for financing (entrepreneur) and according to specific contracts; the obtained profit or loss is divided between depositor and entrepreneur. By receiving commission $(\mathrm{Jol})$, bank provides capital management services for depositors, and invests their resources according to their choices and in return, provides them by Rastin Certificate. Bank has to use all his specialized potentialities to protect depositors' rights.

${ }^{3}$ Project is a collection of economic activities with specified and concrete plan with defined cost and terms for making profit through Rastin PLS banking offered to PLS bank.

${ }^{4}$ Entrepreneur is a real person or legal entity who proposes a project to PLS bank for financing through PLS banking system and executes the project until the end. In addition to have legal, financial, technical and performance capabilities, the entrepreneur should have the other capabilities and facilities/possibility to carry out the job. 
mostly based on the cognition of the entrepreneur; therefore, social networks, which have produced circles of people and friends, can be used as an informative base for introducing the entrepreneur's project. Regarding this method of financing, various kinds of crowd financing can be introduced in the form of grants (without repayment and as a gift), or, loans (with repayment but without interest return).

Since financial procedures require various technical, financial, economic and legal bases and rules, therefore, without providing necessary rules and in the absence of necessary background for these activities, there is no

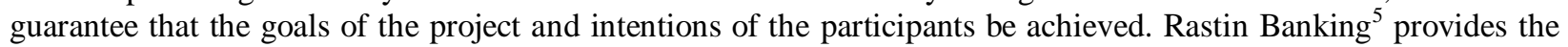
necessary background for financial participation of people; therefore, by using this infrastructure and based on standards, processes, and working procedures of Rastin Banking, crowdfunding can also be installed and executed. Rastin Banking has been designed in modular form, so it enables the bank to expand Rastin Banking activities whit activating the corresponding module. Many of instruments, subsystems and supplementary systems can be applied according to the selected module, and crowd financing uses specific parts of these systems.

Two kinds of crowd financing are defined here as Sponsor Crowd Funding (SCF) and Peer to Peer Loan (PPL) as financial subsystems in the framework of other Rastin Banking financial subsystems ${ }^{6}$. Crowd Funding System (CFS) is also designed to facilitate web-based marketing and money transfer in the two latter subsystems through social networks.

\section{Sponsor Crowd Funding (SCF)}

Sponsor Crowdfunding is absorption and collection of peoples' funds for a specified protective goal in which according to the proposal ${ }^{7}$ of entrepreneur for a specified protective activity, bank after assessment of entrepreneur's proposal will collect needed fund from people and after deducting its own commission without receiving any interest will pay it to entrepreneur. No Rastin certificate ${ }^{8}$ is issued in SCF financing. In SCF, the sponsors ${ }^{9}$ can pay their protective fund to a person, group of people, or governmental and non-governmental organizations. Entrepreneur or beneficiary can be a real person or legal entity. The domicile of the entrepreneur and place of the project can be inside or outside of the country. In any case, the guarantees should be placed within the country and be enforceable and executable in the country. In any case, the goal of the entrepreneur should be specified and be in accordance with regular laws and regulations of the country. Goals of the proposal can be protection and financing various projects among which are:

- Hygiene, Medicare, and rehabilitation

- Education and research

- Innovations and inventions

- Ceremonies, memorials, celebrations, and mourning

- Sport and competition

- Unexpected events and emergencies

- Electoral, political, social, and cultural campaigns to protect specific person/s or subject/s

- Establishment of scientific, political, social, religious and cultural societies

- Environmental, animals, and plants

- Travel and accommodation

- Marriage, dowry, marital gift (Mahriah) and family

- Gifts and celebrity respects

- Repairs, equipment, and parts

- Patronage

\footnotetext{
${ }^{5}$ Rastin PLS banking documents are accessible through: http://www.bidabad.com

${ }^{6}$ Financial subsystems of Rastin PLS banking system refer to different defined financing methods and services. These subsystems are governed by Rastin PLS Base System's regulations.

${ }^{7}$ Proposal is a written document covering a collection of necessary information about the proposed project that describes analytical justification of the project from economic, technical and financial points of view, with enclosed necessary legal licenses and documents; which is submitted to Rastin PLS bank by entrepreneur. After evaluation of the bank if be approved, proposal will be a reference source against entrepreneur executive operations.

${ }^{8}$ Rastin Certificates are a collection of certificates designed and issued in the base system and financial subsystems of Rastin PLS banking.

${ }^{9}$ Sponsor is a real or legal person who pays an un-refundable money to protect a project of entrepreneur of beneficiary via the bank.
} 
- Books, journals, and multimedia

- Unitarian fates and religions

- Art, music, and film

- Release of prisoner

- Job creation

- Establishment and construction

Bank will introduce the proposal of the entrepreneur to people interested in participating in the entrepreneur's project via web-based Crowd Funding System (CFS) and social networks. Financing a project via the Base System ${ }^{10}$ or Financial Subsystems of Rastin PLS banking will not prevent financing a portion of the project resources through SCF. However, in the latter case (twin financing), the entrepreneur is obliged to include both methods in the project proposal delivers to the bank at the same time. Application of twin methods for venture capitals and risky investments, knowledge-based companies, innovations, and inventions are necessary due to risky quality of these type of projects.

The total amount of the project resource requirement could cover assessment, supervision, and bank commission expenses. The project proposal includes a maximum amount of the project's required resources, starting and finishing date of the project. After the deadline or fulfilling the necessary collected fund; the bank will close the project in its website and will not accept deposit (sponsors) payments for the project anymore.

Assessment of project proposal in SCF will be in the direction of legitimacy and truth-checking. The assessment unit $^{11}$ will not assess the profitability of the project. The degree and method of applying Rastin Banking regulations concerning financial transparency of entrepreneur and information disclosure and corporate governance of entrepreneur's company and auditing will be determined according to assessor's conclusion considering avoiding unnecessary formalities and requirements.

The entrepreneur will be bound to provide the bank with necessary guarantees for better implementation of the project and true usage of the collected resources according to the proposal. Cheques and drafts of entrepreneur or other persons are accepted by the bank in this subsystem, as far as they can maintain the confidence of the bank. The amount of guarantee will be equal to the amount of the proposal plus a prevailing margin of the bank in determining guarantees' amounts. After fulfillment of the project, guarantees will be released after confirmation of trustee unit ${ }^{12}$ according to the proposal. In addition, all legal options rights of the sponsor are negated and s/he cannot ask for refund her/his money back.

Trustee unit supervision is limited to good performance and supervision on the way of spending the collected fund from sponsors according to the project proposal. The collected funds are safe-kept and are registered according to Rastin PLS Accounting Regulations. ${ }^{13}$ Bank commission for SCF subsystem services is one percent of the total amount of collected fund, which will be deducted from the provided collected fund. For providing SCF services for assessment and supervision, the bank will also charge the entrepreneur at most equal to one-third of the costs of assessment and supervision in Rastin Banking Operational Bylaw for economic-beneficial projects.

\footnotetext{
${ }^{10}$ Rastin Profit and Loss Sharing (PLS) Base System is an activity in Rastin Banking based on participation of depositors in investment and economic activities of entrepreneur based on real yield of projects in order to land interest-free banking according to Islamic commandments and ethics.

${ }^{11}$ Assessment unit is a unit in PLS department of Rastin PLS bank which assesses the competence and capabilities of entrepreneur and his proposal.

${ }^{12}$ The trustee unit is a unit at PLS department of Rastin PLS bank for supervision and control of Rastin PLS proposed projects on behalf of bank regarding good performance of project in comparison to initial proposal through key indicators and financial reports and supervision for final delivery of the project.

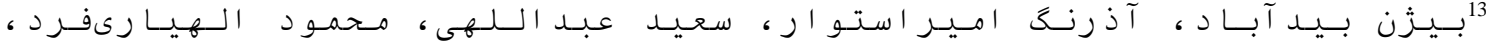

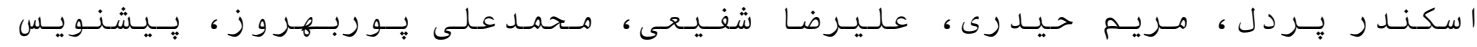

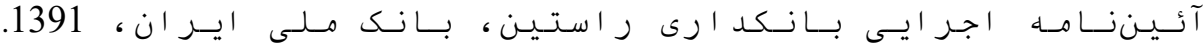$$
\text { http://www.bidabad.com/doc/rastin-banking-regulation.pdf }
$$ 
In case of finding any corruption in the project proposal or delinquency in implementing it, or in any case that implementation of the proposal is excused or stopped for any kind of reason, the entrepreneur must pay back the received fund to the bank and compensate the occurred losses. In the case of his refusal, without going into legal processes, the bank is allowed to confiscate the principle and losses from the entrepreneur's guarantees and is obliged to pay the collected money back to sponsors. If the bank cannot reach the sponsors for any reason, it has to keep the money in its intermediary account for up to 10 years and after that consider it as "unknown owner" asset.

SCF financing of a project can be carried out by using other banking network channels at the same time. The bank is obliged to publish the details of activities and documents of the project proposal from the time of accepting it until a year after the end of the project in its CFS website.

Bank will provide necessary conditions for introducing SCF subsystem at its CFS website and provide the link of its electronic payment port in social networks. Bank will design its CFS website in such a way that the information regarding SCF projects will automatically be updated in the bank's user accounts and fan pages in prevailing social networks. The amount of collected fund should be online shown publicly at social fan pages of bank and entrepreneur. Entrepreneur in the SCF project has to announce his user identification and social fan pages codes and addresses to the bank so the bank could update information in regarded pages.

\section{Peer-to-Peer Loan (PPL)}

Peer-to-Peer Loan is defined as a financial subsystem in Rastin Banking. It is absorption and collection of individual funds for extending interest-free loans to the entrepreneur's project through the bank. No Rastin certificate is issued in PPL financing.

Bank after receiving project proposal of entrepreneur and related documents concerning the details of the proposed project will assess them and if needed, will obtain necessary inquiries about the documents from authorized persons, and prepares a memorandum of understanding (MOU) concerning the proposal with the entrepreneur. Depositors will provide the bank with funds for financing the entrepreneur. After absorption and collection of the necessary fund according to the proposal, the collected fund will be extended to the entrepreneur in a lump sum, or at predefined dates (as specified in the proposal) based on interest-free loan contracts and after receiving or deducting bank's commission fee and assessment and supervision costs.

The entrepreneur can be a real person or legal entity. Entrepreneur's place of residence and place of implementing project may be within or outside of the country. In the latter case, the collaterals and guarantees should be located within the country and should be enforceable and executable by internal laws.

Bank will announce the project proposal through its CFS portal and social networks to interested people for the collection of the fund. Financing the project through other Rastin Banking Financial Subsystems does not conflict with financing through PPL; but in this case (twin financing), the entrepreneur should mention all applied financing methods in his project proposal.

The amount of project finance can include assessment, supervision, and commission fees of the bank. The project proposal has a specified ceiling amount, starting and finishing and due dates, and after the specified termination date in the project, or after collection of the specified fund, the bank will close the project proposal in its CFS portal and fan pages of social networks, and after then no more funds for the project is accepted.

The assessment of the PPL project proposal will be in the direction of its legitimacy and truth testing. The degree and method of applying Rastin Banking regulations concerning financial transparency, information disclosure, corporate governance and auditing about entrepreneur's company will be considered and ruled according to the needs while assessment will take place to avoid unnecessary steps and complexities. The assessment unit will not assess the profitability or cost-benefit analysis of the project.

The entrepreneur is obliged to provide the bank with the necessary guarantees and collaterals for the good performance of the project. The amount of these guarantees and collaterals should be equal to the amount of the extended fund plus the prevailing bank's margin. Guarantees and collaterals will be released after finalizing the 
project. The lender who has financed the project has no right to withdraw his total or a part of the fund he has paid to the project before maturity. The aggregated funds are safe-kept and are registered according to Executive Bylaw of Rastin Banking Accounting standards.

Entrepreneur in PPL financing is obliged to pay the received fund back to the bank according to the due dates defined in the project proposal, and after deducting commission, the bank will pay the remaining fund back to lenders. In the case of un-fulfillment of the obligations of the entrepreneur, the bank will compensate the losses of the lenders through guarantees and collaterals of the entrepreneur. The commission of bank for providing PPL services is equal to one and a half percent of the provided funds that will be deducted from the extended fund. For providing PPL subsystem services of assessment and supervision, the bank will also charge at most one-third of the costs of assessment and supervision in Rastin Banking Operational Bylaw for economic-beneficial projects.

Bank will provide necessary conditions for introducing PPL subsystem in its CFS portal and social networks' pages. Bank will design its CFS portal in such a way that the included information regarding PPL projects will be automatically updated in social networks' pages and accounts of bank and entrepreneur. The collected funds should be shown online at social network fan pages of bank and entrepreneur at any moment (online) to the public.

\section{Crowd Funding System (CFS)}

Crowd Funding System (CFS) is a web-based system for collection of funds for financing SCF and PPL projects in Rastin Banking through social networks. Bank will design its CFS portal in such a way to possess the following capabilities:

- Content Management System (CMS) and social networks connection capabilities.

- Dimensions of webpages should be responsive and adjustable to different sizes of monitors and smartphones.

- Should possess Rich Site Summary (RSS) capabilities and consider its standards.

- The portal information should be automatically sent to, and update fan pages in prevailing social networks.

- In the showcase of the projects, the portal should have shortcuts to social networks so that the user could be able to share, recommend, like, or follow the posts.

- The graph of the trend of promoters and patrons activities of the project should be displayed during the project implementation period.

- URL of each project should be automatically shared or tweeted in social networks during a defined period (promoter capability).

- Tagging, status updating, plugins, questioning, and application programs (App) characteristics should be used in social networks in case of need.

- Customized strategies and marketing advertisements should be used in social networks for introducing the products.

- Necessary strategies for creating fan pages and advertisements based on the bank's brand should be used in social networks' pages.

- The interactive relationship between audience and success of messages, necessary tools for monitoring the traffic and number of Link Clicks, Forwards or Retweets, Comments (feedbacks), Sharing, Recommendations, Likes or Follows and other concepts should be considered.

The bank is bound to establish CFS website with the following capabilities:

- Electronic payment through smart ATM domestic cards and international cards such as VISA, MASTER, EXPRESS and AMERICAN cards (subject to accessibility to international payment ports).

- Support various exchanges.

- Support various languages.

- Connection to international integrated networks such as $\mathrm{SEPA}^{14}$ SWIFT $^{15}$, and other transaction service providers such as PAYPAL and API $^{16}$ (in case of agreement with the card issuer and money transfer service providers).

14 Single Euro Payment Area (SEPA)

15 The Society For Worldwide Interbank Financial Telecommunication (SWIFT)

${ }^{16}$ Arab Payments and Securities Settlement Initiative (API) 
- Using $\mathrm{ACH}^{17}$ for small and ARTGS ${ }^{18}$ for large amounts of money transfer.

- Using IBAN ${ }^{19}$ international identification and other integrated identification methods.

- Electronic payment system.

- Connection to electronic money transfer systems such as RTGS ${ }^{20}$, ACH, Inter-Bank Information Exchange network, and $\operatorname{SSSS}^{21}$.

- Connection to NSSSS ${ }^{22}$ of Central Bank.

- Electronic capabilities for authentication, integrated registration and keeping information of clients, technical specification and necessary capital of the project, documents and contracts to be launched systematically into Crowd Funding System (CFS) and social network pages.

- Links to information of entrepreneurs and projects without the need to launching in Crowd Funding System (CFS).

- Possibility of filtering and other database tools for resorting different projects and entrepreneurs according to different regions, cities, and other conventional parameters in reporting systems.

- Information portal for Rastin Crowd Funding (RCF) projects via different distributive channels.

- Providing showcases, complete bar, number of participants, and other necessary options.

- Integration with other internal and external financial systems and core banking subsystems.

- International data transfer standards.

- Accounting and record-registering operations, client's desk, record tracking, and workflow management, auditing, monitoring, controlling, and supervision.

- Report generating according to the needs of various management levels, experts, and clients.

- Providing financial engineering tools and analytical services.

- Coding of projects and financial documents according to international standards.

- Payment transfer insurance through systems such as FDIC ${ }^{23}$ and others.

- Mobile, telephone, and other communication support for transactions and payments.

- Possibility of using Unstructured Supplementary Service Data (USSD) to prepare facilities for client payment through phone communication operators.

- Possibility of using Near Field Communication (NFC) to prepare smartphone transactional operations.

Bank will provide the appropriate Apps for smartphones with different operating systems for easy access to CFS financing portal. Bank will provide necessary conditions for connection to the electronic payment portal for CFS website and social networks.

By installing necessary security systems, the bank is bound to provide proper security for clients' operations. Security definition should be based on multi-factor authentication. Firewalls, account activity auditing, Virtual Private Network (IPsec VPN, SSL VPN), Intrusion Prevention System (IPS), Webguard, Syslog, Simple Network Management Protocol (SNMP), Computer Security Incident Response Team (CSIRT), Penetration Test, Network Security and Operation Center, standards and considerations of data security should be observed in bank's data network architecture.

The bank is bound to consider more advanced security systems for large transactions. Definition of "large transaction" is done by the bank's management. By receiving the client's account number and security codes, the bank should upload all other client's information at the webpage. By clicking the accept button, the client confirms the information. At each stage of the transaction, the client's identity and account numbers are the bases for verification. The bank is obliged to define a unique identification number for each client. By using unique international identification and account numbers, the bank is obliged to design its system in such a way that the client can interact internationally. The bank is bound to provide the possibility of managerial reporting for different accessing levels with different query parameters in its website.

\footnotetext{
${ }^{17}$ Automated Clearing House

${ }^{18}$ Automated Real-Time Gross Settlement (ARTGS)

${ }^{19}$ International Bank Account Number (IBAN)

20 Real Time Gross settlement System (RTGS)

${ }^{21}$ ScripLess Security Settlement System (SSSS)

${ }^{22}$ Non-Usury ScripLess Security Settlement System (NSSSS)

${ }^{23}$ Federal Deposit Insurance Corporation (FDIC)
} 
The bank is obliged to design its CFS system in such a way that in the cases of excuse (impossibility of executing) and termination of the project that necessitates refunding the money back to sponsor or lender, the possibility of restoring their account numbers be provided.

The main sections of CFS include information portal, registration and membership, project profiles, number and amount of participation (sharing) in each project, place (country) of the project, accessible social networks for the projects, links of social networks to the projects, links to electronic payment portal of bank, management reporting, staged registration software, entrepreneur's profile and uploading necessary documents and confirming them according to user's authorization.

- Information and conditions of all projects are presented to the public at an information portal. Project proposal and information about the entrepreneur (real or legal) (balance sheet, profit, and loss statement and other financial reports for legal entities) and other necessary documents should be published at information portal.

- Manuals of using the website, introduction to CFS, different sections, and method of membership and entrance to the website should be explained at the information portal. This section should be so defined to fulfill the main part of the questions of clients about the CFS website.

- All clients should fill an application form for using CFS services at the registration page.

- By obtaining an electronic banking account number, after registration client will have a unique identification code. This user code will be used to identify him at the website. After entering the CFS portal, the client will go to the registration page and enters his identification code and electronic mail address. Name and user code of the client will be emailed to him.

- For financial participation, the client should enter his name and user code and after approving the conditions of CFS and its commission fee, will be allowed to enter to this section. At this page, the client can monitor conditions of all projects' information and their latest amounts and number of participants. In case of willingness to participate in a project, after entering to financial page of the website, he will click the considered project and will put it in his purchasing basket. Then he will go to pay for his sponsoring money.

- Bank can announce all information about the latest conditions of the projects to all CFS website members through social networks as well.

- The total amount of the client's purchasing basket should not exceed the amount of money he has at his banking account. In case of deficit, he will receive a message to eliminate some items from his purchasing basket.

- After confirmation of the client's offer, a copy of it will be left in his mailbox. All activities on this confirmed offer will be sent to him by short messages and other available distributive channels.

The entrepreneur will announce his user code, and social network pages address to the bank so that the bank can send them information updates systematically. The collected amount for each project at any time interval according to ACH information timing will be shown and updated at the CFS website, and social networks of the bank will be updated and published publicly. The bank is bound to provide backup-monitoring for all CFS activities to trace and follow up. After the accomplishment of the project, all collected fund through the website will be settled with the entrepreneur, and the project will be closed in the website showcase and related social networks pages.

\section{References}

بيزن بيدآباد، آذرنح امير استوار، سعيد عبداللهى، محمود الهيارىفرد، اسكندر يردل، مريم حيدرى، عليرضا شفيعى، محمدعلى بوربهروز، بيشنويس

http://www.bidabad.com/doc/rastin-banking-bill.pdf لايحه قانونى بانكدارى راستين، بانكى ملى اير اندئ، 1391.

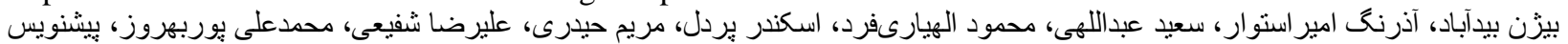

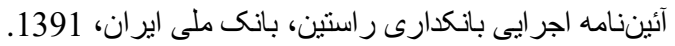

http://www.bidabad.com/doc/rastin-banking-regulation.pdf

بيزّن بيدآباد، طرح تفصيلى تأمين مالى جمعى راستين (RCF). اداره كل تحقيقات، برنامهريزى و مديريت ريسك، بانك ملى ايران. 1393. http://www.bidabad.com/doc/detailed-rcf.pdf

Bidabad, Bijan, New Operational Islamic Banking System, Volume Three, Legal Issues, Lap Lambert Academic Publishing, OmniScriptum GmbH \& Co. KG, 2015. 
Bidabad, Bijan. (2014). New Operational Islamic Banking System, Volume One, Theoretical Foundations, LAP Lambert Academic Publishing, OmniScriptum GmbH \& Co. KG, ISBN: 978-3-659-54463-7.

Bidabad, Bijan. (2014). New Operational Islamic Banking System, Volume Two, Applicational Issues, LAP Lambert Academic Publishing, OmniScriptum GmbH \& Co. KG, ISBN: 978-3-659-55210-6.

Bidabad, Bijan (2018), General Regulatory Framework in Rastin Profit and Loss Sharing Banking (Part IOperational Context). Journal of Business and Finance in Emerging Markets, JBFEM, [S.1.], v. 1, n. 1, p. 1126, May. ISSN 2580-5568. https://doi.org/10.32770/jbfem.vol111-26 http://www.bidabad.com/doc/rastin-regulatory-en-I.pdf

Bidabad, Bijan (2018), General Regulatory Framework in Rastin Profit and Loss Sharing Banking (Part II-Legal Groundwork). Journal of Business and Finance in Emerging Markets, JBFEM, JBFEM, [S.1.], v. 1, n. 2, p. 109-126, Nov. ISSN 2580-5568. https://doi.org/10.32770/jbfem.vol1109-126 http://www.bidabad.com/doc/rastin-regulatory-en-II.pdf

Bidabad, Bijan (2019), General Regulatory Framework in Rastin Profit and Loss Sharing Banking (Part IIIAuxiliary Provisions). Journal of Business and Finance in Emerging Markets, JBFEM, May, Vol 2, No. 1, pp. 51-65. ISSN 2580-5568. https://doi.org/10.32770/jbfem.vol251-66 http://www.bidabad.com/doc/rastin-regulatory-en-III.pdf

Brabham, Daren C. (2008), Crowdsourcing as a Model for Problem Solving: An Introduction and Cases. Convergence: The International Journal of Research into New Media Technologies 14:1, 75-90.

Brabham, D. C. (2009). Crowdsourcing the public participation process for planning projects. Planning Theory, $8(3), 242-262$.

Zhao.Y, Zhu. Q. (2012). Evaluation on crowdsourcing research: current status and future direction. Springer science business media.

\section{Copyrights}

Copyright for this article is retained by the author(s), with first publication rights granted to the journal.

This is an open-access article distributed under the terms and conditions of the Creative Commons Attribution license (http://creativecommons.org/licenses/by/4.0/) 